
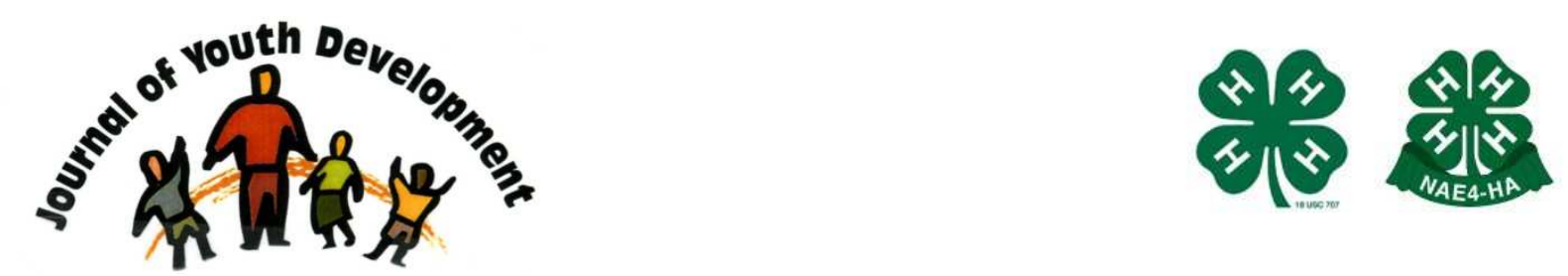

Bridging Research \& Practice

\title{
The Promotion of Character through Youth Development Programs: A View of the Issues
}

\author{
Andrea Vest Ettekal \\ Tufts University \\ Kristina Schmid Callina \\ Tufts University \\ Richard M. Lerner \\ Tufts University
}

Acknowledgement: The preparation of this article was supported in part by grants from the John Templeton Foundation and the Templeton Religion Trust. Author contact information: Andrea Vest Ettekal, Institute for Applied Research in Youth Development, 26 Winthrop Street, Tufts University, Medford, MA 02155. Email: Andrea.Ettekal@tufts.edu 


\title{
JOURNAL OF YOUTH DEVELOPMENT \\ bridging research and practice

\section{The Promotion of Character through Youth Development Programs: A View of the Issues}

Andrea Vest Ettekal, Kristina Schmid Callina and Richard M. Lerner Tufts University

\begin{abstract}
Contemporary developmental theories suggest that outof-school-time (OST) youth development programs may be an important context for character development and education because of the positive, mutually influential relations between youth and adult leaders found in exemplary instantiations of such programs. Although still in its early stages, research about this role of OST programs, including evaluations of specific programs, is burgeoning in relation to increased interest in person-context models of human development. Moreover, tens of millions of American youth participate in several OST programs each year, and there is heightened emphasis among scientists, educators, and policy makers about the importance of promoting character among the diverse youth of the nation. Both to reflect the state-of-the art and in the hope of promoting further research progress, the articles in this special section describe how the attributes of young people and the features of the OST youth development programs in which they participate may link together to promote character development.
\end{abstract}

\section{Introduction}

The Promotion of Character through Youth Development Programs: A View of the Issues Across the past two decades, burgeoning evidence from longitudinal investigations and from evaluation research has indicated that participation in out-of-school-time (OST) youth development programs is associated with thriving across the adolescent years (Vandell, Larson, Mahoney, \& Watts, 2015). Thriving has been indexed through assessment of diverse variables, for instance, purpose, resilience, school engagement, academic skills and achievements, self-regulation abilities, the Five Cs of positive youth development, youth contributions to their families, schools, or communities, and active and engaged citizenship (Lerner, Lerner, Bowers, \& Geldhof, 2015). 
Increasingly, attributes of character - for instance, moral virtues (e.g., integrity, justice, caring, and respect), performance character (e.g., effort, diligence, perseverance, grit, and self-discipline), civic character (e.g., the knowledge, skills, and commitments involved in being an active and positively engaged citizen), or intellectual character (e.g., attributes such as love of learning, seeking truth, creativity, and intellectual humility) - have been the focus of OST youth development programs, either wholly (e.g., through character education programs) or as outcomes of efforts to enhance other facets of thriving (Berkowitz, 2011, 2012; Hilliard et al., 2014; Wang et al., 2015).

\section{Relational Developmental Systems Metatheory and the Study of Character in OST Programs}

The study of the links between character development and youth participation in OST youth development programs lends itself to conceptualization within models derived from relational developmental systems metatheory (Lerner et al., 2015; Overton, 2015). The conceptual emphasis in all models derived from RDS metatheory is placed on the nature of bidirectional relations between individuals and context; these mutually-influential exchanges are represented as individual $\leftarrow \rightarrow$ context relations.

Models constructed within the frame of RDS metatheory focus on the rules, or processes, that regulate exchanges between individuals and their contexts. Brandtstädter (1998) terms these relations developmental regulations and notes that, when developmental regulations involve mutually beneficial individual $\leftarrow$ context relations, they constitute adaptive developmental regulations. The possibility of adaptive developmental relations between individuals and their contexts provides a rationale for believing that the resources, or developmental assets, represented by OST youth development activities (Vandell et al., 2015) may enhance youth thriving, in general, and, arguably, character development in particular.

Within RDS metatheory, character may be conceived of as a specific set of mutually beneficial individual $\leftrightarrow \rightarrow$ context relations and, in particular, individual $\leftarrow \rightarrow$ individual relations that may vary across ontogenetic time and contextual location (place) (Lerner \& Callina, 2014). This RDS-based approach to character development reflects contemporary thinking in both human development and related fields, such as organizational behavior (e.g., Hannah, Campbell, \& Matthews, 2010). As Hannah and colleagues indicate, the bidirectional relations between a person and his/her context, and especially between the individual and other individuals that comprise the context, are important for understanding character development. That is, whereas an RDS-based model of human development always focuses on mutually influential, individual $\leftarrow \rightarrow$ context relations, in the realm of character development we "privilege" one domain: mutually beneficial individual $\leftarrow \rightarrow$ individual relations, such as those between a young person and the adult youth leaders in his or her OST youth development program. Similarly, Nucci (2001) emphasizes that character development involves "human welfare, justice and rights, which are a function of inherent features of interpersonal relations" (p. 7). Moreover, Berkowitz (2012) indicates that character development invariantly involves interpersonal relations that reflect "a public system of universal concerns about human welfare, justice, and rights that all rational people would want others to adhere to" (p. 249). Accordingly, RDS metatheory (Overton, 2015) may be able to productively frame the study of the links between character development and the structure and function of OST programs. .

In sum, developmental theories predicated on RDS metatheory-based ideas suggest that OST youth development programs may be an important context for character development and education because of the positive, mutually influential relations between youth and adult leaders found in exemplary instantiations of such programs (Hilliard et al., 2014; Lerner \& Callina, 2014; Vandell et al., 2015). Accordingly, research about the role of OST youth development programs, including 
evaluations of specific programs, is burgeoning in relation to increased interest in RDS-based models of human development (Lerner, 2015), to the fact that each of tens of millions of American youth participate in several OST programs each years (Vandell et al., 2015), and to heightened emphasis among scientists, educators, and policy makers about the importance of promoting character among the diverse youth of the nation (Berkowitz, 2011, 2012). Yet, such research is still in the early portions of its "ontogeny;" although perhaps beyond its neonatal and infancy periods, research on role of youth development programs in the growth of character is perhaps best characterized as being in its early childhood period.

Accordingly, both to reflect the state-of-the art and, as well, in the hope of promoting further positive development of this domain of applied developmental scholarship, the articles we present in this special issue of the Journal of Youth Development brings together findings from research and program evaluation efforts to begin to understand what specific facets of character development (and other indicators of thriving, if applicable to a given project) may be promoted among what specific youth, by specific substantive features of youth development programs (Bornstein, 2006). Simply, how may the attributes of young people and the features of the OST youth development programs in which they participate link together in promoting character development?

\section{The Articles in Overview}

Boy Scouts of America is a major OST youth development program. Ferris and colleagues (this issue) examined character attributes associated with participation in ScoutReach, a recent innovation in BSA programming designed to deliver the Scouting curriculum to underserved populations. Participants, who were predominantly Black/African American, completed surveys assessing different character attributes (e.g., kindness, helpfulness, hopeful future expectations), and a subset of youth also participated in semi-structured interviews examining character-shaping experiences within the program. Results indicated that involvement in ScoutReach may positively contribute to the development of prosocial behaviors, future career goals, tolerance beliefs, and the ability to apply character attributes across Scouting and non-Scouting contexts.

Shapiro and her colleagues (this issue) note that, whereas OST programs are increasingly recognized as a venue to actively engage children and youth in character development activities, little guidance exists as to how to assess on an individual leve/ character development among participants in OST programs. The authors present a case study about a program that was assessed through the use of a strength-based, multi-modal social-emotional/character assessment, one involving use of both a direct measure and a multiple informant behavior rating scale in an OST setting. Insights derived from the case study reveal opportunities and challenges associated with each assessment modality. The authors offer lessons learned by those individuals conducting the individual assessments and by those seeking to improve our capacity to complete screening, formative, and summative assessments of social-emotional/character attributes in OST youth development programs.

Bowers and his colleagues (this issue) note that, at a time in history when there is an increasing emphasis on the inclusion of character education in both school and out-of-school time programs, digital technologies have become ubiquitous in these settings. Based on the potential of these technologies to enhance children's character development, the Arthur Interactive Media (AIM) study investigated if one specific unit or set of digital media-based activities engaged youth in discussions about character. Although the overall AIM project is intended to reach into children's homes (given the enormous popularity of the animated program, Arthur, among young children) as well as their schools, Bowers and his colleagues discuss initial work involving schools. First and second grade students were paired with $4^{\text {th }}$ and $5^{\text {th }}$ grade students, respectively, while engaging with an online 
interactive graphic novel (IGN) about a character-relevant story based on the Arthur cartoon series. Teachers completed surveys about the AIM unit presented to their students, and conversations between cross-age peer dyads during their engagement with the IGN were analyzed. Results indicated that teachers were very satisfied with the materials and reported that children were very engaged throughout. Analyses of children's conversations indicated that children participated in character-relevant conversations involving humility, forgiveness, and future-mindedness while engaging with the IGN.

Fuentes and colleagues (this issue) used empowerment and ecological theories to frame a pilot assessment of how the Youth Empowerment Solutions (YES) program may facilitate character development through activities based in cultural differences, team building, and social change. This pilot study consisted of two focus groups of middle school youth conducted after their participation in an abbreviated version of the YES program. The authors examined youth cross-cultural perspectives after participation. Coding of focus group responses resulted in the identification of two emergent themes: 1. enhanced appreciation for similarities and differences in cultural and ethnic backgrounds; and 2 . the role of respect in understanding differences and confronting stereotypes. The youth reported that engagement in this program fostered positive awareness of cultural differences and respect for inter-ethnic relationships.

Ettekal and colleagues (this issue) note that, although it is the case that respect is crucial for promoting participation and positive experiences in organized activities, especially among ethnically diverse youth, little is known regarding how Mexican-origin adolescents conceptualize respect and specifically how to promote respect in activities. Guided by theory and previous research, the authors studied Mexican-origin $7^{\text {th }}$ graders who resided in the Southwest of the U.S., an area with a history of inter-ethnic group tensions, and used qualitative content analysis to elucidate perspectives about respect and features of OST activities that promote respect. The adolescents described three different types of respect: humanity respect, respect for culture, and linguistic respect. The authors identified several features of OST activities involved in the development of respect among youth participants, including individual (e.g., moral virtues), contextual (e.g., welcoming atmosphere), and inter-personal (e.g., shared experiences) features.

Chauveron and colleagues (this issue) note that character education programs are mission-aligned with the positive youth development (PYD) perspective, which, in research with American youth, suggests that intentional self-regulation (ISR) develops through mutually beneficial relations between youth and their context. In cross-national studies of Western youth, there is evidence that ISR exists among adolescents as a global, undifferentiated construct. The authors sought to begin to extend this work by assessing the relationship between ISR and PYD in young Scottish adolescents (approximately 7th grade) participating in the "Inspire>Aspire" (I>A) Poster Program, a character education program that creates educational experiences for youth that seeks to foster the values of honesty, generosity, reliability, future mindedness, diligence, thrift, joy, purpose, curiosity, and humility. ISR was correlated with the Five Cs of PYD (Competence, Confidence, Character, Connection, and Caring), and findings from regression analyses demonstrated that ISR predicted two of the Five Cs: Character and Connection.

Also using the I>A data set, MacDonnell and colleagues (this issue) conducted a mixed methods assessment of the connection between ISR and feelings about the chances of achieving future aspirations among Scottish youth. Regression analyses indicated that ISR predicted youth feelings about their chances of achieving future aspirations. Qualitative data suggested the use of ISR skills among adolescents, even when those skills were not evident quantitatively. 
One important instance of youth diversity involves variation in health and ability status, and Maslow and his colleagues (this issue) present results from a pilot evaluation of two PYD programs for youth with child onset chronic illness (COCI). The authors discuss how the programs influenced participants' character development. College students with COCI led high school students with COCI through activities pertaining to different aspects of growing up with a chronic illness. Participants completed the Positive Youth Development Inventory-Short Form (PYDI-S), which measures seven domains of youth perceptions of the contribution to their development from the program. Participants reported that both programs helped them the most with personal standards, which correspond to character development on the full version of the Positive Youth Development Inventory (PYDI). The results also suggested that participants were influenced by the program in regard to prosocial behavior and future orientation, both important domains for character development.

Ferris, Ettekal, and colleagues (this issue) examined high school sports coaches' perspectives about a character-based coach education workshop designed by Positive Coaching Alliance (PCA) to promote positive coaching practices and transform the culture of youth sports. Fifteen coaches provided feedback about the quality of the workshop and what aspects of it they applied to their coaching practices. Results indicated that coaches believed that participation in PCA workshops contributed to the value they attributed to individuals, to coach-oriented character development, and to positive relationships within youth sports. The coaches also suggested changes in future PCA workshops. These findings provide preliminary evidence that coaches incorporate skills acquired through participation in character-based coach education programs.

\section{Conclusions}

Character development arises through mutually influential and mutually beneficial relations between individuals, that is, adaptive individual $\leftarrow \rightarrow$ individual relations (Lerner \& Callina, 2014). OST youth development programs, when implemented well, may involve such relations between the young person and the adult leaders of these programs (Vandell et al., 2015). This possibility, along with interests in the general contribution that OST youth development programs may make to PYD, are associated with the growing but, still early in its development, literature on the links between these OST programs and character development.

The articles we have included in this special section reflect the still-early state-of-the art of this literature but, nevertheless, are quite encouraging in regard to the breadth of ideas being taken to explore the links between OST youth development program participation and character development. Collectively, the authors of the papers we have included both recognize the limitations of the work they have accomplished so far and, as well, reflect a passion for enhancing the efficacy of the capacities of the programs to provide character-enhancing experiences to young people.

By integrating intellectual humility, scientific prudence, research talents, and passion and purpose for their work, we believe that the scholars contributing to this special section will help this domain of research move forward productively. We hope that the articles will also motivate other scholars and practitioners to make additional contributions. If so, then the work we present in this special issue will be seen as part of a productive impetus to the enhancement of integrative knowledge and practice promoting character virtues among diverse children and adolescents through youth development programs. 


\section{References}

Berkowitz, M.W. (2011). What works in values education. International Journal of Educational Research, 50(3), 153-158.

Berkowitz, M.W. (2012). Moral and character education. In K.R. Harris, S. Graham, T. Urdan, S. Graham, J.M. Royer, \& M. Zeidner (Eds.), Individual differences and contextual factors. Volume 2 of APA Educational Psychology Handbook (pp. 247-264). Washington, DC: American Psychological Association.

Bornstein, M.H. (2006). Parenting science and practice. In K.A. Renninger, I.E. Sigel (Vol. Eds.), Handbook of child psychology, Vol. 4: Child psychology in practice (6 ${ }^{\text {th }}$ ed.). (pp. 893-949). Editors-inChief: W. Damon, \& R.M. Lerner. Hoboken, NJ: Wiley.

Brandtstädter, J. (1998). Action perspectives on human development. In R.M. Lerner (Ed.), Theoretical Models of Human Development. Volume 1 of Handbook of Child Psychology (5 ${ }^{\text {th }}$ ed.). (pp. 807-866). Editors-in-chief: W. Damon \& R.M. Lerner. New York: Wiley.

Hannah, S.T., Campbell, D.J., \& Matthews, M.D. (2010). Advancing a research agenda for leadership in dangerous contexts. Military Psychology, 22(S1), S157-S189.

Hilliard, L.J., Hershberg, R.M., Wang, J., Bowers, E.P., Chase, P.A., Champine, R.B., Buckingham, M.H., Warren, D.P.A., Ferris, K.A., \& Lerner R.M. (2014). Program innovations and character in cub scouts: Findings from Year 1 of a mixed-methods, longitudinal study. Journal of Youth Development, 9(4), 4-30.

Lerner, R.M. (2015). Preface. Handbook of Child Psychology and Developmental Science (7th ed.). Editor-in-chief: R.M. Lerner. (pp. xv-xxi). Hoboken, NJ: Wiley.

Lerner, R.M., \& Callina, K.S. (2014). The study of character development: Towards tests of a relational developmental systems model. Human Development, 576), 322-346.

Lerner, R.M., Lerner, J.V., Bowers, E., \& Geldhof, G.J. (2015) Positive youth development and relational developmental systems. In W.F. Overton \& P.C. Molenaar (Eds.), Theory and Method. Volume 1 of the Handbook of Child Psychology and Developmental Science (7th ed.). Editor-in-chief: R.M. Lerner. (pp. 607-651). Hoboken, NJ: Wiley.

Nucci, L.P. (2001). Education in the moral domain. Cambridge, England: Cambridge University Press.

Overton, W.F. (2015). Process and relational developmental systems. In W.F. Overton \& P.C. Molenaar (Eds.), Theory and Method. Volume 1 of the Handbook of Child Psychology and Developmental Science (7th ed.). (pp. 9-62). Editor-in-chief: R.M. Lerner. Hoboken, NJ: Wiley.

Vandell, D.L., Larson, R.W., Mahoney, J.L., \& Watts, T.R. (2015). Children's activities. In M.H. Bornstein and T. Leventhal (Eds.), Handbook of Child Psychology and Developmental Science (7th ed.), Volume 4: Ecological Settings and Processes. (pp. 305-344). Editor-in-chief: Richard M. Lerner. Hoboken, NJ: Wiley. 
Wang, J., Ferris, K.A., Hershberg, R.M., \& Lerner, R.M. (2015). Developmental Trajectories of Youth Character: A Five-Wave Longitudinal Study of Cub Scouts and Non-Scout Boys. Journal of Youth and Adolescence, 1-15. doi:10.1007/s10964-015-0340-y.

(C) Copyright of Journal of Youth Development Bridging Research and Practice. Content may not be copied or emailed to multiple sites or posted to a listserv without copyright holder's express written permission. Contact Editor at: patricia.dawson@oregonstate.edu for details. However, users may print, download or email articles for individual use.

ISSN 2325-4009 (Print); ISSN 2325-4017 (Online) 